Journal of MMIJ Vol.123 p.836-838(2007)

(C)2007 The Mining and Materials Processing Institute of Japan

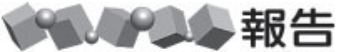

Technical Report

\section{建設副産物のリサイクルの現状と課題 *}

\title{
Current Situation and Issues on Recycling of Construction By-Products
}

\author{
by Hiroaki NIIZUMA ${ }^{\mathrm{a}}$
}

a. Advanced Construction Technology Center, Planning Division, Niissei Otowa Bldg., 4F 2-15-6

Ootsuka Bunkyo-ku Tokyo Japan (Corresponding author E-mail: niizuma@actec.or.jp)

In total, materials of two billion tons are used annually in Japan and the $40 \%$ are used at the construction works. The construction waste is generated in the amount of about 80 million tons a year.

Toward the sustainable society, 3R promotions and newly developed technology are needed in the construction sector.

In this papers, the current situation and issues on recycling technology for the construction by-product are described

KEY WORDS: Construction By-Product, Construction Waste, Recycling Technology

1.はじめに

わが国の建設産業では, 1 年間に全産業で投入される資源約 20 億 $\mathrm{t}$ のおよそ $40 \%$ という膨大な量の資源が投入されている。一方, 道路の新設や維持, 河川改修などの社会資本整備やビル, マンショ ン，戸建住宅などの新設，解体等の建設事業から発生する建設廃 棄物は，年間約 8,000 万 $\mathrm{t}$ が排出されている。

建設事業活動で造り出寸構造物は, 良質で安全性が求められる 社会資本であり，その多くは寿命が到来すると更新されるが，と くに高度経済成長期に全国各地でつくられた多くの建造物が更新 時期を迎え大量の建築物の解体廃棄物の増加が予測されることや 最終処分場の逼迫寸る残余容量など多くの課題を抱えている。

今後, 我が国の循環型社会形成に向けて, 建設産業のリサイク ル推進のための取組みの強化や技術開発の進展が重要である。

\section{2. 建設廃棄物の現状}

全産業から排出される廃棄物は，年間約 4 億 $\mathrm{t}$ ある。建設廃棄 物の発生量, リサイクルされる量, 建設発生土の発生量, 工事間 利用される量, 建設廃棄物の処理を行う施設などを含め, 建設副 産物に関する調查は, 1990 年度から 5 年毎に建設副産物実態調 查として国土交通省が実施している。2005 年度建設副産物実態 調査によれば，建設事業活動に伴って発生する建設廃棄物は，年 間 7,700 万t で産業廃棄物の約 $20 \%$ を占めている。

発生する廃棄物のうち, リサイクルされないで最終処分場で廃 棄される廃棄物の量は, 全産業で 3,000 万 $\mathrm{t}$ 女り，このうち $20 \%$ にあたる 600 万 $\mathrm{t}$ は, 建設廃棄物となる。1995 年度調查での建設

2007 年 2 月 1 日受付 10 月 9 日受理

1. (財) 先端建設技術センター 企画部 参事

[ 著者連絡先 ] FAX: 03-3942-0424

E-mail : niizuma@actec.or.jp

キーワード : 建設副産物, 建設廃衰物, リサイクル技術
廃棄物最終処分量の 4,150 万 $\mathrm{t}$ からみるとこの 10 年での建設リ少 イクル推進の大きかったことが伺える。

建設廃棄物の発生量は, 1995 年度の発生量より約 2,200 万 $\mathrm{t}$ 減 少している。建設廃棄物の品目としては, アスファルト・コンク リート塊, コンクリート塊, 建設污泥，建設発木材，建設混合廃 棄物に大別される。

これら建設廃棄物の排出量, 再資源化量, 再資源化率名等を品 目別に示したものが Table 1 である。

また，再資源化もされず適正な最終処分もされずに不法に投棄 される産業廃棄物は, 2005 年度新たに 17.2 万 t 発覚したが, こ のうちの $80 \%$ 強が建設廃棄物となっている。

\section{3. 建設廃棄物のリサイクルの流れ}

建設廃棄物の発生と再資源化や最終処分の流れは, Fig. 1 のよ うになっている。

建設事業活動に伴って発生する廃棄物は，発注者から直接工事 を請負った施工業者 (元請) が排出事業者責任を負っており，排 出抑制のため, 可能な限り建設現場内での再利用に努めている。 さらに再資源化率の向上や混合廃棄物の削減, 廃棄物の処理, 処 分の費用負担の軽減のため, 分別の徹底に努力している。建設現 場内で再利用できない廃棄物については, 許可を受けた収集・運 搬業者, 廃棄物処理業者と委託契約を結び, 建設廃棄物の運搬, 処理・処分を委託している。建設廃棄物の大部分は, 一旦中間処 理施設に搬入され, そのうち最終処分されるものは, 選別, 脱水, 乾燥, 焼却などの中間処理が施され, 再資源化されるものは, コ ンクリート塊等の破砕, 建設発生木材のチップ化, RDF 化など が行われる。

再資源化されたものは，再資源化施設に引き取られマテリアル リサイクルの原料やサーマルリサイクルの燃料として, 破砕され た再生砕石は工事現場などで再利用される。 
Table 1 Amount of kind of another construction waste and the recycling rate (2005) ${ }^{1)}$

\begin{tabular}{|c|c|c|c|c|}
\hline 品目 & $\begin{array}{l}\text { 排出量 } \\
\text { (万 } \mathrm{t})\end{array}$ & $\begin{array}{c}\text { 再資源化量 } \\
\text { (万 } \mathrm{t})\end{array}$ & $\begin{array}{c}\text { 最終処分量 } \\
\text { (万 } \mathrm{t})\end{array}$ & 再資源化率 (\%) \\
\hline アスファルト・コンクリート塊 & 2,610 & 2,570 & 40 & 98.6 \\
\hline コンクリート塊 & 3,220 & 3,160 & 60 & 98.1 \\
\hline 建設污泥 & 750 & 560 & 190 & 74.5 \\
\hline 建設発生木材 & 470 & 430 & 40 & 90.7 \\
\hline 建設混合廃裹物 & 290 & 80 & 210 & - \\
\hline その他 & 360 & & 60 & - \\
\hline 建設廃莗物全体 & 7,700 & 7,100 & 600 & 92.2 \\
\hline
\end{tabular}

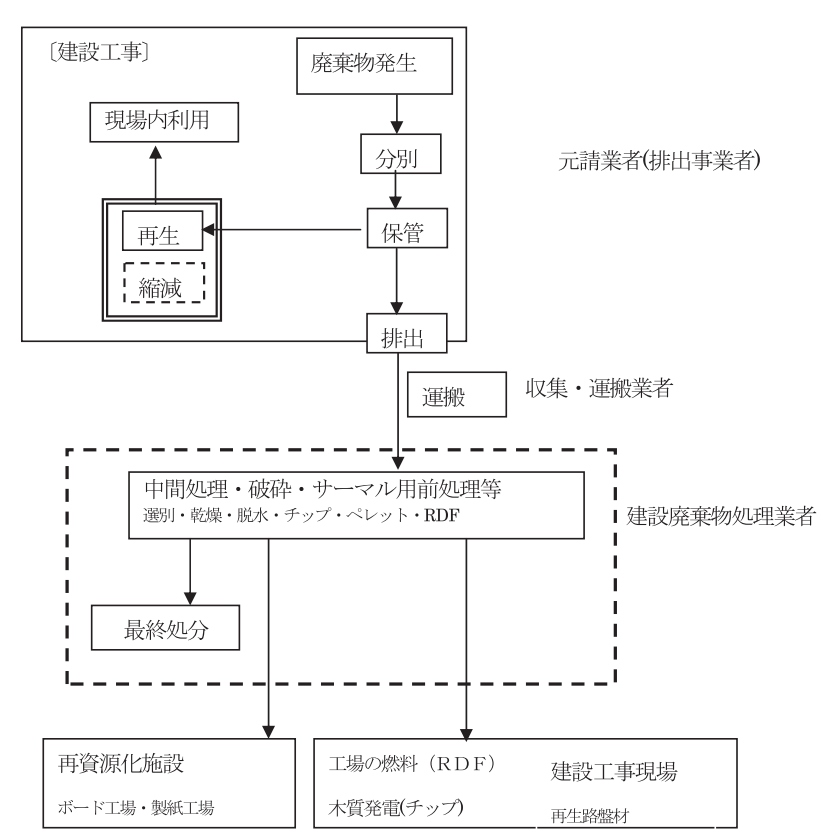

Fig.1 Flow of waste generated from construction work ${ }^{2)}$.

\section{4. 建設副産物品目別のリサイクル技術と現状}

建設廃棄物の品目は, 前述したようにコンクリート塊, アスファ ルト・コンクリート塊, 建設発生木材, 建設污泥, 混合廃棄物に 分類され,それぞれの品目ごとのリサイクルは, 以下のようになっ ている。

\section{$4 \cdot 1$ コンクリート塊}

老朽化したビルの解体工事等から排出されるコンクリート塊 は, 大部分が破砕プラントで $40 \mathrm{~mm}$ 以下に破砕され「再生路盤材」 として再利用されている。コンクリート塊については，既に 98\%を超える高い再資源化率が達成されており，今後その維持が 重要となっているが, 東京オリンピックを契機とした高度経済成 長期以降に建設された建築物が間もなく更新期を迎え，排出量は 増加することが予想されている一方で, 路盤材としての需要だけ でなく新たな利用先の開拓が求められている。このような中, コ ンクリート塊からオリジナルの骨材部分を取り出す「コンクリー 卜再生骨材 H」の JIS が 2005 年 3 月に制定された。

コンクリート塊を破砕しただけの砕石をコンクリート用の骨材 として利用してもモルタルペーストが付着しているため, そのま までは十分な強度のコンクリートを作ることが出来ない。コンク リート塊を加熱や擦り揉み処理を行うことで良質な骨材を抽出す
るこの技術は，コンクリート骨材不足の解消という観点からも実 用化，普及に向けて注目される技術である。「コンクリート塊か ら骨材を取り出して新しいコンクリートをつくる」真の循環の実 現に向けて歩み出したところである。

\section{2 アスファルト・コンクリート塊}

アスファルト・コンクリート塊は, 道路の舗装面の打ち直し等か ら発生する。コンクリート塊と同様に破砕して再生路盤材としての 利用と, アスファルト合材プラントで再加熱しアスファルト量を調 整して再生アスファルト合材として再利用され，あわせて $98 \%$ を 超える高い水準の再資源化率を達成している。しかし, 都市部の 幹線道路や高速道路などで採用が進んでいる排水性舗装等につい ては, 粘性の高い改質アスファルトを含有している等の理由からリ サイクルが困難なため, 新たな技術開発が進められている。

\section{$4 \cdot 3$ 建設発生木材}

建設発生木材は, コンクリート塊, アスファルト・コンクリー 卜塊と同様に「建設リサイクル法」で分別解体および再資源化が 義務付けられた特定建設資材となっているがコンクリート塊など と較べるとリサイクル率が低くなっている。この原因として建設 発生木材は, 戸建住宅等の比較的小さな構造物の解体工事から発 生し, 1 現場あたりの排出量がコンクリートやアスファルト・コ ンクリート等に較べると少ないこと, 焼却などで簡単に処分が容 易であったこと, リサイクルシステムの確立, 施設整備などが後 手に廻っていたこと，再生利用用途が製紙，燃料など建設産業以 外の分野にも跨り, 排出者と利用者の間で木材チップの時期, 品 質等の調整が十分に図られていないことなどが考えられる。国土 交通省では, 2003 年 8 月千葉県佐倉で発生した木材チップの不 適切な保管による自然発火の問題を受け「千葉県における建設発 生木材リサイクル促進計画」を策定した。この計画は千葉県をモ デルとしたものであるが千葉県だけでなく全国的な展開が望まれ るところである。

一方, 木材チップに関しては, 新エネルギーの利用やカーボン ニュートラルということから，木質バイオマスの発電所の稼動や 新設の計画があり燃料用として大量の木材チップ需要が見込まれ ているところである。

\section{$4 \cdot 4$ 建設污泥}

建設污泥は, 都市部のシールドトンネル工事や基礎杭等の工事 で掘削面の崩壊を防止するためにベントナイト等を含む掘削安定 液と土砂が混ざった状態の水分の高い泥土状のものである。建設 污泥の再生利用の用途は, 土質材料の代替として水分の低下を図 り, セメント系の固化材等を加えて改質する。建設発生土が余っ ている状況にあり建設污泥を改質したものを積極的に利用する環 境が整っている状態ではない。土質材料の代替材としての再生利 


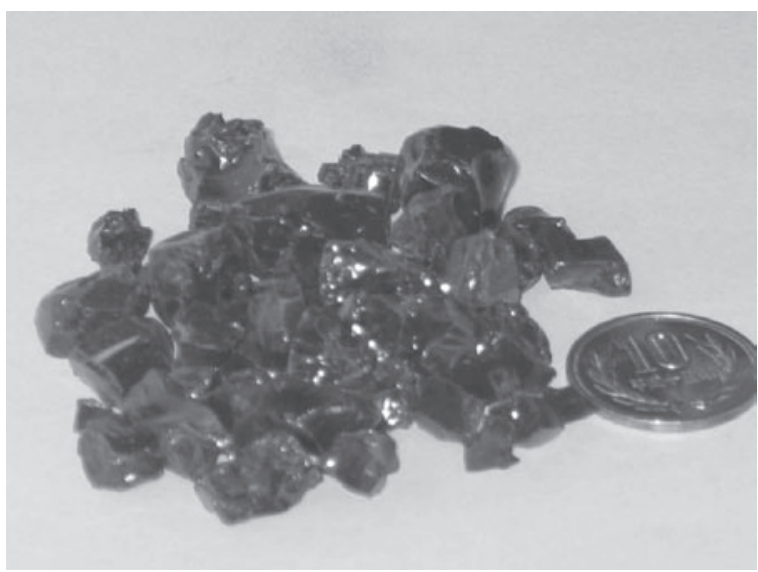

Fig.2 Municipal waste melt slag.

用のほか固化粒状化して路盤材料やドレーン材料としての製品化 する技術も確立しているが他の品質同等品と較ベコスト面での課 題も残っている。国土交通省では，建設污泥を工事間で優先的に 利用する「リサイクル原則化ルール」に位置づけるなど「建設污 泥再生利用に関するガイドライン」等を策定し制度面からリサイ クル推進を図っている。

\section{$4 \cdot 5$ 建設混合廃棄物}

建設混合廃棄物は, 多品目のごみが混ざり合った状態の廃棄物 である。建設現場から発生する廃棄物を再資源化の可能な範囲で 分別に努めることでその量を減らす事が可能である。しかしなが ら都市部の建設現場は, ヤードが狭く多品目の建設廃棄物の分別 ヤードを確保することが困難なこと, 廃棄物の収集運搬の現状の 制度の中でコストアップになることから建設混合廃棄物の減量化 は難題と言うことができる。分別をすることにより再資源化率の 向上や最終処分量の削減が可能となる。これらの問題解決のため に, 建設廃棄物の排出事業者, 廃棄物処理業者など関係者が集ま り建設混合廃棄物の小口分別巡回回収のシステム構築についての 検討を進めている。

また, 近年稼動した最新鋭の大型建設廃棄物処理プラント等で は, 比重差選別の高度化や最新の選別設備を要して建設混合廃棄 物の $90 \%$ を超えるリサイクルを達成し, 最終処分量の削減に貢 献している。

\section{5. 建設副産物リサイクルの課題}

建設産業には，莫大な資源が投入されているが他産業から排出 される副産物の活用も行っている。鉄鋼スラグは, 年間約 2, 500 万 $\mathrm{t}$ 程度排出されますがその殆んどは，高炉セメントや路盤 材料, 土工材料として, また家庭から出る一般廃棄物を溶融固化 したスラグなども道路用やコンクリート用の骨材として利用の検 討が進められている。Fig. 2 は一般廃棄物溶融スラグである。

建設副産物のリサイクルについては, 順調にリサイクルの推進 が図られてきた。しかしながら, 石綿やPCBをはじめとした有
害廃棄物の問題, 建設廃衰物の不法投棄, 廃棄物ではありません が建設発生土の有効利用など様々な問題を抱えている。石綿建材 や不法投棄問題について以下に記す。

\section{$5 \cdot 1$ 石綿建材の問題}

2005 年 7 月から「石綿障害予防規則」が制定されたが，時を 同じくして石綿による健康被害 (中皮腫) の問題が連日のように マスコミを賑わした。

石綿の問題は, 1980 年代の後半に学校や体育館などの教育施 設の随所に石綿の使用が判明した時, 阪神・淡路大地震の倒壞建 築物の処理を合わせて今回 3 回目である。過去の 2 回は, 石綿の 危険性が指摘され，吹き付け石綿の除去とか処分の問題であった が，今回は健康被害が現実のものとなったことでより多くの人た ちが関心を示している。

石綿は, 耐熱性, 気密性, 柔軟性などに優れ, また安価である ことから我が国では 1960 年以降 2000 年まで約 1,000 万 $\mathrm{t}$ 程度が 輸入され，このうちの $80 \%$ は建設資材として使用されたと推定 されている。今後の建築物解体は, アスベス卜建材とそうでない ものとの分別解体が, リサイクルの上でも重要となる。

\section{$5 \cdot 2$ 解体廃棄物の増大と不法投棄問題}

高度経済成長期の建築物の更新の状況によっては, 解体廃棄物 が増加することが考えられる。一方, 鉄鋼スラグをはじめ他産業 の大量の副産物を引き受けているが, 公共事業の規模の変化に よっては, リサイクルの環に歪みの出ることも懸念される。

建設リサイクルの更なる推進には, 普及・啓蒙活動の充実の必 要性を感じている。建設産業の特徴として重層構造で関係者が非 常に多く, すべての関係者に建設リサイクルの問題を正しく理解 してもらうともに, 高度情報処理技術等による新たなシステムの 構築で全不法投棄の $80 \%$ 以上を占める建設廃棄物の根絶を図る 必要があると思われる。

\section{6.おわりに}

「建設リサイクル法」の制定による特定建設資材の分別と再資源 化の義務付け,「グリーン購入法」による環境物品等の調達により, 資源循環型社会の形成の枠組みは出来上がってきた。

今後は, 構造物の長寿命化や既存の構造物の維持管理, 更新技 術などの技術開発を行い, 建築物の解体を(廃棄物の発生抑制) 減らす方向へ転換し資源循環型社会の実現に向けて進んでゆくこ とを期待している。

(財) 先端建設技術センターでは, 建設副産物のリサイクル推 進方策やリサイクル技術に関寸る調查研究と建設リサイクルに関 する広報の推進を行っている。建設リサイクルの更なる進展に向 けて努力してゆく所存である。

\section{References}

1) The Ministry of Land, Infrastructure and Transport investigation, (2005).

2) Conference for announcing to public reproduction of construction by-product : Explanation of construction by-product propriety processing promotion outline (Taisei shuppansya. Tokyo, 2002). 